and nothing could be more simple or satisfactory than breast feeding which is going well. What must be faced is that there is a considerable chance that it will not go well and, if a mother is having difficulty with breast feeding or is unwilling to maintain it, it is more practical and better for both physical and mental health that she should be carefully educated in how to bottle feed properly than cajoled into persisting with breast feeding.

\title{
REFERENCES
}

Abels, J. (r949). Brit. med. F. i, 154.

Antonov, A. N. (1947). F. Pediat. 30, 250.

Best, W. R. (1954). F. Lab. clin. Med. 44, 768.

Food and Agriculture Organization of the United Nations: Committee on Calorie Requirements (1957). FAO nutr. Stud. no. 15.

Gunther, M. (1945). Lancet, 249, 590.

Gunther, M. (1956). Lancet, 270, i75.

Hytten, F. E. (1954a). Brit. med. F. i, 249.

Hytten, F. E. (1 954b). Brit. med. F. ii, 844 .

Hytten, F. E. \& Thomson, A. M. (1955). Brit. med. F. ii, 232.

Hytten, F. E., Yorston, J. C. \& Thomson, A. M. (1958). Brit. med. F. i, 3 Io.

Interdepartmental Committee on Physical Deterioration (1904). Report of the Interdepartmental Committee on Physical Deterioration. [Cd. 2210]. London: H.M. Stationery Office.

Morse, J. L. (I935). F. Pediat. 7, 303.

Naish, F. C. (1948). Breast Feeding. London: Oxford University Press.

Ross, A. I. \& Herdan, G. (1951). Lancet, 260, 630.

Smith, C. A. (1947). Y. Pediat. 30, 229.

Taylor, H. L., Buskirk, E. R., Brožek, J., Anderson, J. T. \& Grande, F. (1957). Y. appl. Physiol. ro, $42 \mathrm{I}$.

Yorston, J. C. \& Hytten, F. E. (1957). Proc. Nutr. Soc. I6, vi.

\section{The nutrition of young animals}

\section{By T. R. Preston, Rowett Research Institute, Bucksburn, Aberdeenshire}

In this paper I shall consider nutritional aspects of problems encountered in the rearing of calves and pigs under normal farm practice. Apart from man, these are the only mammals commonly reared both artificially and naturally and also they afford interesting examples of two widely different physiological types, namely ruminants and simple-stomached animals.

\section{Natural rearing}

The usual method of rearing pigs is to let the sow suckle them until they are 8 weeks old. A sow's milk yield begins to decline about the $3^{\text {rd }}$ or $4^{\text {th }}$ week of the $7^{\frac{1}{2}}$ weeks' lactation (Gill \& Thomson, 1956; Lodge, 1957), and to enable the young to attain their maximum rate of growth it is usual to provide ad lib. supplementary feeding in the form of a dry meal. The major problem in natural rearing is anaemia which tends to occur only when the piglets are raised indoors or on concrete. The pig is born with low reserves of iron (Venn, McCance \& Widdowson, 1947) and there 
is little iron in sow's milk; neither source can be influenced appreciably by iron supplementation of the sow's diet (Foot \& Thompson, 1938-9; Venn et al. 1947). The usual method of preventing anaemia is to dose the piglet at weekly intervals with a solution containing iron (Foot \& Thompson, 1947-8; Venn et al. 1947; Barber, Braude \& Mitchell, I955 $a$;) or, a recent innovation, to give a single intramuscular injection of iron (Barber, Braude $\&$ Mitchell, $1955^{b}$; Brownlie, 1955). Anaemia due to copper deficiency has been reported (Teague \& Carpenter, 195I) but it is not common.

In contrast to pigs only a small proportion of calves is suckled by their dams, the majority are reared artificially, receiving varying amounts of cow's milk or cow'smilk substitute from a bucket. Natural rearing by suckling is seldom practised in dairy herds because of the value of cow's milk for human consumption and the consequent competition for its use. Suckling is the accepted method for rearing pedigree beef animals but is only economically applicable to the rearing of commercial beef cattle on hill or marginal land, where the rearer qualifies for considerable subsidies. Mortality amongst beef calves suckled by their mothers is low, and generally the technique is fairly free of trouble except where the diet of the gestating animal is of poor quality. In this respect Blaxter \& Brown (1952) have reported an incidence of muscular dystrophy of $20-25 \%$ in suckled beef herds in the north of Scotland. The typical rations there, oat straw and swedes, are low in vitamin $\mathrm{E}$, consequently the colostrum and milk, the main source of vitamin $\mathrm{E}$ for the calf, contain insufficient amounts of the vitamin. The condition can be prevented by feeding to the cow conserved greenstuff, either silage or dried grass. Blaxter, Sharman \& Macdonald (1957) have also described an anaemia due to iron deficiency in suckled calves kept indoors without access to concentrates or roughages.

\section{Artificial rearing}

Since Johnson, James \& Krider (1948) produced a synthetic substitute for sow's milk there has been a great deal of interest in methods for rearing pigs artificially. This interest was, in the first instance, of an experimental nature and was directed towards the rearing of pigs which were: (I) delivered by hysterectomy and thence maintained in a disease-free environment; (2) weaned from the sow at 2 days old and subsequently fed on synthetic liquid-milk diets; and (3) weaned from the sow at Io days old on to a dry meal mixture. Recently the third method has been exploited commercially since it is claimed that it offers certain advantages over natural rearing, namely more pigs reared per litter, heavier and more uniform pigs at 8 weeks old, an extra litter every 2 years and a saving in food to the sows.

Delivery by hysterectomy and subsequent raising of the pigs in disease-free isolation units on artificial colostrum of cow's milk supplemented with whole eggs and minerals is necessarily a very specialized technique (Young \& Underdahl, 1953), and has been employed mainly as an aid to the study of pig diseases. Without such elaborate precautions the successful rearing of pigs denied colostrum is almost impossible (Johnson et al. 1948; Catron, Nelson, Ashton \& Maddock, 1953; Bellis, 
1957), for the pig, unlike man, relies on colostral transfer of immunity as the placenta is impervious to antibodies (Young \& Underdahl, I949, I950).

Synthetic liquid-milk diets for 2-day-old pigs which have received colostrum have been based on casein, glucose, lard, minerals and vitamins (cf. Johnson et al. I948) and others have been composed mainly of cow's milk supplemented with fats, sugars, minerals and vitamins (cf. Catron et al. 1953). Antibiotics have been invariably included in these diets. Such milk substitutes have been reconstituted with water to contain about $\mathrm{I} 5 \%$ solids and usually have been fed from open troughs. Growth and mortality of pigs so reared have been variable: $6 \mathrm{r} \%$ deaths between 3 days and 8 weeks old was recorded in one series of experiments (Smith \& Lucas, 1956). The system has not found much application on farms except where very large litters have been born-part would be reared on milk substitute-or if a sow has farrowed and yielded a negligible quantity of milk.

The system which has had most success in farm practice is to wean the pig at Io days old and then give a dry meal mixture with water provided separately (Crampton \& Ness, 1954; Speer, Ashton, Diaz \& Catron, 1953-4; Smith \& Lucas, 1956). In general, diets have been based on dried skim-milk powder with added starch, glucose, sucrose, fish meal, minerals, vitamins and antibiotics.

At first the weaned pig eats very little and there is a check period immediately after weaning which lasts from 3 to 15 days. Food and water are then consumed in increasing amounts and growth is very rapid; at 8 weeks the artificially reared pig is as heavy as, and often heavier than, pigs reared naturally.

The calf, like the pig, depends upon colostrum for passive immunity to infectious disease (Smith \& Little, I922). When colostrum is not available, as when a cow has been milked regularly before parturition, the best substitute would appear to be whole milk supplemented daily with $200 \mathrm{mg}$ chlortetracycline (Roy, Shillam, Palmer \& Ingram, 1955). The calf may be left to suckle its dam for the first 3 days or given colostrum from a bucket. Subsequently it may be given whole milk or a reconstituted synthetic, or semi-synthetic, milk substitute. The latter may be substituted for whole milk at any stage from 4 days old onwards. Generally liquid feeding continues until the calf is between 8 and 12 weeks old when it is weaned on to dry meal and roughage. A recent development in calf rearing has been to curtail liquid feeding to the first $3-5$ weeks of life; this technique will be considered more fully later.

Mortality in artificially reared calves is about $8 \%$ (Withers, 1952) and follows a seasonal pattern with most losses occurring in spring and least in autumn (Jordan, 1933; Withers, 1952). Many authorities have attempted to associate this seasonal loss with the amount of green forage, and hence the carotene, in the prepartum diet (Jordan, r933; Walker, 1948; Payne, 1949) although attempts to alleviate scours, the most prevalent trouble, in spring-born calves by vitamin $A$ therapy have failed (Aschaffenburg, Bartlett, Kon, Roy, Sears, Thompson, Ingram, Lovell \& Wood, 1953). 
Nutritional requirements

Skim-milk powder and glucose have formed the basis of most synthetic pig and calf diets, but a high proportion of these ingredients is uneconomic in practice. Other sources of nutriment have to be found but unfortunately the search for alternatives has not proved very rewarding.

Carbohydrates. Johnson (1949) was one of the first to investigate the value of sucrose for the day-old pig. He found that, though glucose could be included in the diet at levels of up to $56 \%$, replacing it with sucrose caused severe diarrhoea and very poor growth. The inability of very young pigs to utilize sucrose was confirmed by Becker, Ullrey \& Terrill ( I 954) who showed that 2-day-old baby pigs developed severe diarrhoea $18 \mathrm{~h}$ after they were given sucrose and by $96 \mathrm{~h}$ half of them had died. Diarrhoea appeared to result from the sucrose passing down the gut undigested and thus having a hydragogue action in the colon. The authors noted that after 7 days the surviving pigs showed some ability to utilize sucrose. Several workers have shown that pigs over 7 days old can tolerate 10-20\% sucrose in the diet without ill effect (Lewis, Catron, Combs \& Ashton, r953; Smith \& Lucas, r956), in fact by this stage, if given a choice, pigs prefer a diet containing $20 \%$ sucrose to one with no added sucrose (Lewis et al. r953).

Starch is not a satisfactory energy source in a diet for the 2-day-old pig (Cunningham \& Brisson, 1955, I957a) and although McCrea \& Tribe (1956) included maize starch as $25 \%$ of such a diet with seemingly good results their report is an isolated one. Good utilization of starch by 7 -day-old pigs is reported by Becker et al. (1954) but Smith \& Lucas (1956) found that it did not give as good results as sucrose. The relative value of different carbohydrates for pigs from 7 to 10 days old is summarized by Hudman, Speer, Ashton \& Catron (1955) who obtained live-weight increases between $\mathrm{I}$ and 5 weeks of $\mathrm{I0} \cdot 6,8 \cdot 6,8 \cdot 3,6 \cdot 9$ and $6 \cdot 9 \mathrm{lb}$. for purified diets containing lactose, sucrose, glucose, maize starch and oat groats respectively.

Fat. The dry matter of most liquid-milk substitutes fed to 2-day-old pigs has contained about 30\% lard (Johnson et al. I948; Wise, Barrick, Wise \& Osborne, 1954). Such diets must be homogenized (McCrea \& Tribe, I956). There is evidence that the fat globules should be reduced in size to less than $0.5 \mu$ in order to be absorbed through the lymphatic system since only a small proportion of fat may be hydrolysed before absorption (Frazer, 1952; Garton \& Duncan, 1954). In this connexion it is perhaps relevant that Lloyd \& Crampton (1957) found an inverse relationship between the mean molecular weight of a fat and its apparent digestibility by 3 -weekold pigs.

Addition of arachis oil to dry meal mixtures (to give $7 \%$ ether extractives in the diet) had little effect on growth rate of pigs weaned at 10 days but did improve efficiency of food conversion (Smith \& Lucas, 1956). Increased growth was obtained by adding $10 \%$ maize oil but the diets (containing $13 \%$ ether extractives) were noticeably oily and feeding equipment became sticky and difficult to keep clean (Crampton \& Ness, I954). On the other hand, inclusion of $2 \%$ cod-liver oil improved the consistency of otherwise dusty meal mixtures (Smith \& Lucas, 1957). 
Protein. In general, the source of protein in synthetic liquid-milk diets has been casein or skim-milk powder. The only investigation with 2-day-old pigs has been made by Bellis (I957), who obtained less efficient growth when the ratio of dried skim milk to fish meal was decreased. Substitution of fish meal for skim milk has been successful in diets for pigs weaned at Io days; Lucas (1957) found no difference in growth rate or efficiency of food conversion when skim milk was replaced entirely by an equivalent amount of protein as fish meal.

The inability of the very young pig (under 7 days old) to utilize sucrose and starch, the superiority of casein over fish meal as a source of protein, and the increasing tolerance to these carbohydrates and to fish meal with advancing age, suggest that at birth the digestive system of the pig is not developed to the point of being able to utilize efficiently foods the adult pig would receive normally. But this is to be expected since in the course of evolution the young pig has come to depend entirely on its mother's milk for at least the first 3 weeks of life, after which it begins to look for additional sources of food.

Confirmation of this hypothesis is claimed by Bailey, Kitts \& Wood (1956) and Kitts, Bailey \& Wood (1956) in their reports on the activity of various enzymes in the digestive tract of young pigs. Their findings suggest that whereas activity of lactase and lipase was high at birth that of amylase, sucrase and maltase was negligible. The hydrolysing power of these last three enzymes increased as the pig became older and by 3 weeks seemed to be fairly well developed. Lactase activity appeared to decline with age, which is in agreement with the finding that, whereas the young pig can tolerate high levels of lactose (Becker et al. I954), reduced appetite and poor growth were recorded when diets containing $50 \%$ lactose were fed to 9 -week-old pigs (Becker \& Terrill, I954).

There appears to be no conclusive evidence on the rate of development of proteolytic enzymes in the pig. Kvasnitski \& Bakeeva (1940) reported that gastric secretions of newborn pigs contained pepsin and rennase but that there was no hydrochloric acid in the stomach until ro-30 days of age. They noted that the stomach contents were acid, but attributed this to fermentation products of the gut microflora.

Workers at Iowa, U.S.A., found that pigs weaned at ro days grew better on skimmilk diets than when the protein was from soya-bean meal. They claimed from results of trials with 1000 pigs that supplementing the latter diet with pepsin improved growth on the average by $6 \%$. There was no response when pepsin was added to a skim-milk diet (Lewis, Catron, Liu, Speer \& Ashton, 1955; Baker, Lewis, Wilbur, Hartman, Speer, Ashton \& Catron, 1956). The results were variable-the response ranged from $-8 \%$ to $+40 \%$ and, as the authors of the earlier paper noted, 'The possibility exists that part of the response to enzyme supplementation may be due to unidentified growth factors in the crude preparations or even to improvement in amino acid balance'. Other workers, so far, have been unable to confirm these findings (Cunningham \& Brisson, 1957 $b$; Terrill, 1957).

In many respects the nutritional requirements of the young calf given a liquid diet parallel those of the young pig. As early as 1918 Shaw, Woodward \& Norton 
(I9I8) demonstrated that the young calf could not digest appreciable quantities of starch until it was 4 weeks old and Flipse, Huffman, Duncan \& Webster (1950) and Flipse, Huffman, Webster \& Duncan (1950) reported greater weight gains when lactose rather than starch was the carbohydrate source in a synthetic milk. Diarrhoea was much more frequent in the starch-fed group. In a study with 9-month-old calves given food direct into the abomasum Larsen, Stoddard, Jacobson \& Allen (1956) found that, although glucose and maltose produced a rise in blood sugar, starch and ground maize had no effect and appeared in the faeces comparatively undigested. Poor results from inclusion of starch in syntheticmilk diets have been reported by Maynard \& Norris (1922) and Shoptaw, Espe \& Cannon (1937). There is little published evidence on enzyme activity in the calf but a recent report by Dollar \& Porter (1957) appears to substantiate many of the above findings. The results of their experiment indicated that whereas orally administered solutions of lactose and glucose produced a rapid rise in blood glucose, maltose and sucrose produced only a small rise and starch and dextrin produced none. The authors claimed that their findings were corroborated by enzyme-activity studies (unpublished work) which showed a high lactase activity at birth subsequently decreasing with age, and a low amylase and maltase activity which increased with age. It is debatable whether starch hydrolysis, if it did occur, would be sufficiently rapid to affect blood glucose levels, yet their results together with the other evidence would suggest that for calves $1-4$ weeks old, lactose and glucose are the only suitable carbohydrates for inclusion in a synthetic-milk diet.

Fat, usually lard, has been satisfactorily incorporated in synthetic-milk diets but it must be emulsified and homogenized since Kastelic, Bentley \& Phillips (1950) noted that the particle size should be less than $2 \mu$ diameter to prevent scouring.

Concerning the protein requirements of the young calf it appears that the enzyme system, pepsin- $\mathrm{HCl}$, is not developed at birth, for when synthetic milk (not coagulated by rennet) with a calcium : sodium ratio of $0.9: 0.7$ was fed to 2-day-old calves, they all died, whereas the same milk produced adequate growth in 7 -day-old calves (Kastelic et al. 1950).

Other nutrients. For essential amino-acids and fatty acids, vitamins and minerals, the piglet and the young calf have requirements similar to those of the young of the rat, dog and man and no further reference to them will be made in this review.

\section{Onset of rumen function}

So far the calf's requirements have been considered in relation to the first few weeks of its life during which time it can be considered to behave as a monogastric animal--by virtue of the action of the oesophageal groove which allows liquids to by-pass the rumen and reticulum (Comline \&. Titchen, I95 I). This state, though nutritionally more efficient than that of the adult ruminant, economically puts the calf at some disadvantage. While the calf behaves as a simple-stomached animal its diet must be composed of expensive foods such as whole milk or reconstituted dried-milk products for which the cost per unit of starch equivalent is about $1 / 3 \mathrm{~d}$ or $\mathbf{I} / \mathrm{-}$, respectively. But once it becomes a functional ruminant it can be fed on a 
diet costing only $5 \mathrm{~d}$. or $6 \mathrm{~d}$. per unit of starch equivalent. The onset of efficient rumen function is therefore of major importance since the sooner the calf becomes a functional ruminant the more cheaply it can be reared.

Development of the four compartments of the ruminant stomach begins early in foetal life (Lambert, 1948). At birth the rumen has a capacity of 21 ., about the same as the abomasum. The rumen grows slightly while the calf is receiving milk but the major stimulus to its development is the ingestion of solid food. Roughage brings about the greatest increase in the capacity of the rumen but the functional lining of the rumen-the papillas-are developed equally by concentrates or hay (Warner, Flatt \& Loosli, I956). The popular theory that fibrousness of the diet is entirely responsible for rumen development is disputed by these workers, who found that nylon bristle inserted and left in the rumen induced no papillary development even after 70 days. It appears that chemical entities, rather than coarse materials, are the stimuli for growth and development of rumen tissue.

Small quantities of food, such as straw and milk, probably begin to collect in the rumen in the first few days of life and on this substrate there will develop a fairly characteristic population of micro-organisms. Evidence of early fermentation in the rumen was provided by the finding of McArthy \& Kesler (1956) that volatile fatty acids appeared in the blood and rumen liquor of the calf within $I$ week of birth. Rumen movements in calves of this age have also been recorded (Benzie, 1957). Preston, Archibald \& Tinkler (1957) showed that 3-week-old calves were able to digest the dry matter of fresh grass as efficiently as the adult ruminant. Rumination in calves given early access to solid food begins when they are between 2 and 3 weeks old (Preston, 1957b), and it is probable that in such calves the rumen becomes fully functional about this time. In theory, therefore, it should be possible to feed the 3 -week-old calf as a ruminant, with all the attendant advantages of microbial synthesis of proteins and B vitamins from simple food constituents. Such a system of rearing has been described by Preston (1956, 1956-7), who showed that calves made adequate growth when weaned from milk at 3 weeks old and subsequently given a simple dry meal mixture, hay and water. It is too soon to evaluate fully the postweaning requirements of the early-weaned calf although certain aspects have been discussed in a recent review of this subject (Preston, 1957a). Success with this method of rearing depends on accustoming the young calf to eat dry meal, and in this respect physical texture and palatability of the meal are probably as important factors as its chemical composition. The preponderance of lactobacilli in the rumen of the young calf (Mann \& Oxford, 1954, 1955) and the likelihood, when carbohydrate-rich foods are given, of an excessive production of lactic acid (Phillipson, I952) with consequent ill effects (Hungate, Dougherty, Boyant \& Cello, 1952), are factors which militate against too early dependence on concentrate digestion in the rumen. Inclusion of low levels of antibiotics in such a diet (Preston, 1956) may be a necessary prophylaxis against possible digestive upsets from this cause. 
REFERENCES

Aschaffenburg, R., Bartlett, S., Kon, S. K., Roy, J. H. B., Sears, H. J., Thompson, S. Y., Ingram, P. L., Lovell, R. \& Wood, P. C. (1953). Brit. F. Nutr. 7, 275.

Bailey, C. B., Kitts, W. D. \& Wood, A. J. (1956). Canad. F. agric. Sci. 36, 5 I.

Baker, R. O., Lewis, C. J., Wilbur, R. W., Hartman, P. A., Speer, V. C., Ashton, G. C. \& Catron, D. V. (1956). J. Anim. Sci. 15, 1245.

Barber, R. S., Braude, R. \& Mitchell, K. G. (1955a). Vet. Rec. 67, 543.

Barber, R. S., Braude, R. \& Mitchell, K. G. (1955b). Vet. Rec. 67, 348.

Becker, D. E. \& Terrill, S. W. (1954). Arch. Biochem. 50, 399.

Becker, D. E., Ullrey, D. E. \& Terrill, S. W. (1954). Arch. Biochem. 48, 178.

Bellis, D. B. (1957). Proc. Nutr. Soc. 16, 98.

Benzie, D. (x957). Personal communication.

Blaxter, K. L. \& Brown, F. (1952). Nutr. Abstr. Rev. 22, I.

Blaxter, K. L., Sharman, G. A. M. \& MacDonald, A. M. (1957). Brit. F. Nutr. II, 234.

Brownlie, W. M. (1955). Vet. Rec. 67, 350 .

Catron, D. V., Nelson, L. F., Ashton, G. C. \& Maddock, H. M. (1953). F. Anim. Sci. 12, 62.

Comline, R. S. \& Titchen, D. A. (I95 I). F. Physiol. II5, 210.

Crampton, E. W. \& Ness, O. M. (1954). F. Anim. Sci. 13, 357.

Cunningham, H. M. \& Brisson, G. J. (1955). Canad. F. agric. Sci. 35, 37 I.

Cunningham, H. M. \& Brisson, G. J. (1957a). F. Anim. Sci. 16, 370.

Cunningham, H. M. \& Brisson, G. J. (1957b). F. Anim. Sci. 16, 568.

Dollar, A. M. \& Porter, J. W. G. (1957). Nature, Lond., r79, r 299.

Flipse, R. J., Huffman, C. F., Duncan, C. W. \& Webster, H. D. (1950). J. Dairy Sci. 33, 557.

Flipse, R. J., Huffman, C. F., Webster, H. D. \& Duncan, C. W. (1950). F. Dairy Sci. 33, 548.

Foot, A. S. \& Thompson, S. Y. (1938-9). Y. Minist. Agric. 45, 452.

Foot, A. S. \& 'Thompson, S. Y. (1947-8). F. Minist. Agric. 54, 308.

Frazer, A. C. (1952). Biochem. Soc. Symp. no. 9, p. 5.

Garton, G. A. \& Duncan, W. R. H. (1954). Biochem. Y. 57, 20.

Gill, J. C. \& Thomson, W. (1956). F. agric. Sci. 47, 324.

Hudman, D. B., Speer, V. C., Ashton, G. C. \& Catron, D. V. (1955). F. Anim. Sci. 14, 1209.

Hungate, R. E., Dougherty, R. H., Bryant, M. P. \& Cello, R. M. (1952). Cornell Vet. 42, 423.

Johnson, B. C., James, M. F. \& Krider, J. L. (1948). F. Anim. Sci. 7, 486.

Johnson, S. R. (1949). Fed. Proc. 8, 387.

Jordan, L. (I933). Vet. F. 89, 202.

Kastelic, J., Bentley, O. G. \& Phillips, P. H. (1950). F. Dairy Sci. 33, 725.

Kitts, W. D., Bailey, C. B. \& Wood, A. J. (1956). Canad. F. agric. Sci. 36, 45.

Kvasnitsk1, A. V. \& Bakeeva, E. N. (1940). Trud. Inst. svinovod. Kiev, 15, 5. Quoted in Vet. Bull. (I943) $\mathrm{r}_{3}, 222$.

Lambert, P. S. (1948). Vet. F. 104, 302.

Latsen, H. J., Stoddard, G. E., Jacobson, W. L. \& Allen, R. S. (1956). F. Anim. Sci. 15, 473.

Lewis, C. J., Catron, D. V., Combs, G. E. \& Ashton, G. C. (1953). F. Anim. Sci. 12, 923.

Lewis, C. J., Catron, D. V., Liu, C. H., Speer, C. V. \& Ashton, G. C. (1955). F. agric. FdChem. 3, 1047.

Lloyd, L. E. \& Crampton, E. W. (1957). F. Anim. Sci. 16, 377.

Lodge, G. A. (1957). Personal communication.

Lucas, I. A. M. (1957). Personal communication.

McArthy, R. D. \& Kesler, E. M. (1956). F. Dairy Sci. 39, 1280.

McCrea, M. R. \& Tribe, D. E. (I956). Vet. Rec. 68, 74I.

Mann, S. O. \& Oxford, A. E. (1954). F. gen. Microbiol. rr, 83 .

Mann, S. O. \& Oxford, A. E. (1955). F. gen. Microbiol. r2, I40.

Maynard, L. A. \& Norris, L. C. (1922). Proc. Amer. Soc. Anim. Prod. p. 75.

Payne, W. J. A. (I949). Brit. F. Nutr. 3, i.

Phillipson, A. T. (1952). Brit. F. Nutr. 6, 190.

Preston, T. R. (1956). Proc. Brit. Soc. Anim. Prod. p. 67.

Preston, T. R. (1956-7). Agriculture, Lond., 62, 462.

Preston, T. R. (1957a). N.A.A.S. Quart. Rev. no. 35, p. I 8.

Preston, T. R. (1957b). Unpublished.

Preston, T. R., Archibald, J. D. H. \& Tinkler, W. (1957). F. agric. Sci. 48, 259.

Roy, J. H. B., Shillam, K. W. G., Palmer, J. \& Ingram, P. L. (1955). Brit. F. Nutr. 9, 94.

Shaw, R. H. Woodward, T. E. \& Norton, R. P. (1918). F. agric. Res. 12, 575.

Shoptaw, L., Espe, D. L. \& Cannon, C. Y. (I937). F. Dairy Sci. 20, I I 7.

Smith, T. \& Little, R. S. (1922). F. exp. Med. 36, I81.

Smith, H. \& Lucas, I. A. M. (1956). F. agric. Sci. 48, 220. 
Smith, H. \& Lucas, I. A. M. (I957). F. agric. Sci. 49, 409.

Speer, V., Ashton, G., Diaz, F. \& Catron, D. (1953-4). Iowa Fm Sci. 8, no. Io, p. 3.

Teague, H. S. \& Carpenter, L. E. (195I). F. Nutr. 43, 389.

Terrill, S. W. (1957). Personal communication.

Venn, J. A. J., McCance, R. A. \& Widdowson, E. M. (1947). \%. comp. Path. 57, 314.

Walker, D. M. (1948). Studies in the nutrition of young dairy stock. Doctorate Thesis, University of Reading.

Warner, R. G., Flatt, W. P. \& Loosli, J. K. (1956). F. agric. Fd Chem. 4, 788.

Wise, M. B., Barrick, E. R., Wise, G. H. \& Osborne, J. C. (1954). F. Anim. Sci. 13, 365 .

Withers, F. W. (1952). Brit. vet. F. 108, 315.

Young, G. A. Jr. \& Underdahl, N. R. (1949). Cornell Vet. 39, 120.

Young, G. A. Jr. \& Underdahl, N. R. (1950). F. Immunol. 65, 369.

Young, G. A. \& Underdahl, N. R. (1953). Amer. F. vet. Res. 14, 57 I.

\title{
Idiopathic hypercalcaemia of infants
}

\author{
By R. G. Mitchell, Department of Child Health, University of St. Andrews
}

\section{Clinical features}

During the past 4 years, eighteen infants with the simple type of idiopathic hypercalcaemia have been treated in Dundee. The age of onset of symptoms ranged from the $3^{\mathrm{rd}}$ to the gth month, with the highest incidence in the 6 th and $7^{\text {th }}$ months. The clinical picture was remarkably consistent, the principal symptoms being anorexia, loss of weight, vomiting and constipation. About half of the infants showed fretfulness or apathy whereas the remainder were happy, contented infants despite their symptoms. In five of the eighteen cases there was a history of apparent difficulty in swallowing, an observation of some interest since Albright \& Reifenstein (1948) record this as a symptom of hypercalcaemia in adults.

Most of the infants were poorly nourished although this was not an invariable finding. Clinical dehydration was present in six of the eighteen on admission, but faecal masses were palpable in the abdomen of only two. The infants showed no consistent colour change, two having excessively red cheeks and two being unusually pale. A cardiac murmur was heard in three of the infants: in ten there were pus cells in the urine.

Hypercalcaemia was not diagnosed unless plasma-calcium determinations on two separate occasions showed levels above $12 \mathrm{mg} / 100 \mathrm{ml}$. At some time in their illness, all eighteen infants had a level of plasma calcium of ${ }_{3} 3 \mathrm{mg} / \mathrm{r} 00 \mathrm{ml}$. or over, and in two the level rose above $18 \mathrm{mg} / 100 \mathrm{ml}$. The blood urea level was above $50 \mathrm{mg} / 100 \mathrm{ml}$. in eleven of the eighteen. Levels of plasma cholesterol and alkaline phosphatase were variable and showed no consistent abnormality.

\section{Role of vitamin $D$}

The clinical features and the fact that calcium-balance studies had shown a high rate of calcium absorption from the intestine, suggested the possibility of a vitamin 